\title{
RENATA PODGÓRZAŃSKA
}

Szczecin

\section{Perspektywy integracji państw pojugosłowiańskich z Unią Europejską}

\section{Wprowadzenie}

Zmiany polityczne i gospodarcze zachodzące w Europie Środkowej i Wschodniej miały swój odpowiednik w procesach, jakie nastąpiły w części południowo-wschodniej kontynentu. Przeobrażenia te - ich przebieg i charakter - różniły się jednak zasadniczo od transformacji w naszej części Europy. Nowy układ geopolityczny w Europie Południowo-Wschodniej kształtował się pod wpływem kilkuletnich działań wojennych, co doprowadziło do demontażu Socjalistycznej Federacyjnej Republiki Jugosławii (SFRJ) ${ }^{1}$. Proces jej rozpadu rozpoczął się wraz z ogłoszeniem deklaracji niepodległości przez dwie z sześciu republik - Chorwację i Słowenię - w czerwcu $1991 \mathrm{roku}^{2}$. W ślad za Chorwatami i Słoweńcami kolejne republiki domagały się prawa do suwerenności. W ciągu kilku miesięcy niepodległość ogłosiły Macedonia oraz Bośnia i Hercegowina. Serbia i Czarnogóra w 1992 roku utworzyły Federacyjną Republikę Jugosławii. W latach 2003-2006 w jej miejsce powstała nowa luźna federacja pod nazwą Serbia i Czarnogóra. Na skutek niepodległościowych aspiracji potwierdzonych referendum, Czarnogóra w 2006 roku ogłosiła niezależność; oddzielając się od Serbii, stała się kolejnym suwerennym państwem na Bałkanach. W lutym 2008 roku niepodległość ogłosiła zaś serbska prowincja Kosowo.

Powstałe na gruzach federacji jugosłowiańskiej suwerenne państwa dziś są określane mianem państw pojugosłowiańskich (lub postjugosłowiańskich) ${ }^{3}$. W przeważającej

1 Jugosławia była państwem federacyjnym, złożonym z sześciu republik: Serbii, Chorwacji, Słowenii, Macedonii, Czarnogóry oraz Bośni i Hercegowiny i dwóch autonomicznych prowincji.

2 O przyczynach rozpadu Jugosławii szerzej: E. Bujwid-Kurek, Państwa pojugosłowiańskie. Szkice politologiczne, Kraków 2008, s. 19-66; M. Kuczyński, M. Ray-Ciemięga, Bałkański syndrom 1991-1999, Warszawa 2000; M. Waldenberg, Rozbicie Jugosławii. Od separacji Stowenii do wojny kosowskiej, Warszawa 2003; M. Waldenberg, Rozbicie Jugosławii. Jugostowiańskie lustro międzynarodowej polityki, Warszawa 2005; S. Wojciechowski, Integracja i dezintegracja Jugosławii na przełomie XX i XXI wieku, Poznań 2002; I. Rycerska, Rozpad Jugosławii. Przyczyny i przebieg, Kielce 2003; M. Kuczyński, Krwawiqca Europa. Konflikty zbrojne i punkty zapalane w latach 1990-2000. Tło historyczne i stan obecny, Warszawa 2001; W. Szulik, Konflikt w byłej Jugosławii, „Sprawy Międzynarodowe" 1997, nr 1, s. 91-108; M. Tanty, Batkany XX wieku, Warszawa 2003; J. J. Wiatr, Europa pokomunistyczna. Przemiany państw i społeczeństw po 1989 roku, Warszawa 2006, s. 96-108; J. Wojnicki, Przeobrażenia ustrojowe państw postjugosłowiańskich (1990-2003), Pułtusk 2003; J. Wojnicki, Proces instytucjonalizacji przemian ustrojowych $w$ państwach postjugostowiańskich, Pułtusk 2007; M. J. Zacharias, Komunizm, federacja, nacjonalizmy. System władzy w Jugosławii 1943-1991. Powstanie - przeksztatcenia - rozktad, Warszawa 2004.

3 Stosowane w literaturze terminy ,państwa pojugosłowiańskie” lub ,państwa postjugosłowiańskie” odnoszą się do części składowych Socjalistycznej Federacyjnej Republiki Jugosławii. W wyni- 
większości ich status prawny jest unormowany. Są one równoprawnymi uczestnikami stosunków międzynarodowych. Nikt nie podważa ich prawa do samodzielności, jedynie wobec Kosowa sytuacja nie jest uregulowana ${ }^{4}$. Spory o prawo do samostanowienia Kosowa rozpoczęły się w momencie podejmowania decyzji przez władze w Prisztinie 5 . Społeczność międzynarodowa różnie oceniała decyzję władz w Kosowie, na co wpływały różnorodne uwarunkowania. Państwa akceptujące niezależność Kosowa, w tym część państw Unii Europejskiej oraz USA, uznały ogłoszenie niepodległości Kosowa za końcowy akt rozpadu Jugosławii, stwarzający podstawy do pokojowej współpracy na Bałkanach. Państwa przeciwne secesji Kosowa uznały zaś ów krok za niezgodny z prawem międzynarodowym, za wyraz dominacji państw zachodnich stwarzający niebezpieczny precedens i zagrażający stabilności i bezpieczeństwu europejskiemu. Argumentowano, że deklaracja niepodległości Kosowa jest niezgodna z prawem międzynarodowym i postanowieniami konferencji helsińskiej KBWE o nienaruszalności granic państwowych w Europie oraz sprzeczna z wewnętrznym prawem Serbii. Wskazywano że może to się stać podstawą do przyszłych precedensów, ze strony innych narodów domagających się niepodległego bytu ${ }^{6}$. Podnoszono również problem destabilizacji państw, które z trudem budują swoją tożsamość w wyniku rozpadu Jugosławii ${ }^{7}$. Z uwagi na niestabilną sytuację polityczną, słabość gospodarczą, problemy wynikające z różnorodności etnicznej i religijnej zamieszkujących je społeczności obawiano się ,reakcji łańcuchowej”. Zwracano również uwagę na szanse samodzielnej egzystencji ekonomicznej nowego państwa, jego stabilności, bezpieczeństwa wewnętrznego, przyszłych stosunków sąsiedzkich ${ }^{8}$. Niezależnie jednak od emocji towarzyszących niepodległości Kosowa, wciąż trwających dyskusji, mimo nieuznawania jej przez niektóre państwa członkowskie UE, państwo to funkcjonuje na arenie między-

ku demontażu federacji w latach 1991-2008 uzyskały one status samodzielnych państw - Chorwacja, Słowenia, Macedonia (Była Jugosłowiańska Republika Macedonii - FYROM), Bośna i Hercegowina, Czarnogóra, Serbia. Do tej grupy można zaliczyć jeszcze Kosowo. Z uwagi na skomplikowany status Kosowa i nieuznawanie jego niepodległości przez dużą grupę państw, w tym kilka europejskich, istnieją poważne wątpliwości co do jego państwowości. Por. E. Bujwid-Kurek, Państwa pojugosłowiańskie..., s. 7 i n.; J. Wojnicki, Przeobrażenia ustrojowe..., s. 13 i n.

4 Obecnie Kosowo jako niepodległe państwo zostało uznane przez 69 krajów, w tym USA i 22 z 27 krajów Unii Europejskiej. Spośród krajów UE nie uznały niepodległości Kosowa: Cypr, Grecja, Hiszpania, Rumunia i Słowacja.

17 lutego 2008 r. parlament Kosowa na specjalnej sesji jednomyślnie (przy bojkocie posiedzenia przez 11 przedstawicieli serbskich) uchwalił 12-punktową deklarację niepodległości prowincji. Zob. Kosova Declaration of Indipendence, http://www.assembly-kosova.org/common/docs/declaration indipendence.pdf.

${ }^{\overline{6}}$ Zob. Konflikty zbrojne na obszarze postradzieckim. Stan obecny. Perspektywy uregulowania. Konsekwencje, „Prace Ośrodka Studiów Wschodnich”, z. 9, czerwiec 2003; M. Topczewska, Separatyzmy narodowe w Europie Zachodniej, „Studia Europejskie” 2001, nr 1.

7 Zagrożony może być np. byt Bośni i Hercegowiny. Serbowie zamieszkujący to państwo, posiadając już znaczący stopień niezależności od rządu w Sarajewie, zapowiedzieli możliwość secesji z federacyjnej Bośni (na mocy porozumienia zawartego w Deyton Bośnia i Hercegowina składa się z dwóch części - Federacji Bośni i Hercegowiny oraz Republiki Serbskiej). Sytuację zaognił parlament Serbów bośniackich, który przyjął rezolucję, w której wspomniał o możliwości referendum w sprawie oderwania się Republiki Serbskiej od Bośni i Hercegowiny. Zob. A. Skieterska, Serbowie z Bośni też chcq niepodległości, „Gazeta Wyborcza”, 23-24 II 2008.

8 J. Kumoch, M. Janik, Serbowie boja się zemsty, „Dziennik”, 19 II 2008. 
narodowej. W lipcu 2010 roku Międzynarodowy Trybunał Sprawiedliwości potwierdził legalność ogłoszenia niepodległości Kosowa ${ }^{9}$. Czy zatem secesja Kosowa była ostatnim aktem rozpadu b. Jugosławii? Przedmiotem niniejszego artykuły będzie próba odpowiedzi na to pytanie. Problem ten będzie rozpatrywany w kontekście niezwykle skomplikowanych warunków, w jakich funkcjonuje wieloetniczna Bośnia i Hercegowina.

Stosunek społeczności międzynarodowej wobec niepodległości państw, które do początku lat dziewięćdziesiątych XX wieku były częścią składową Socjalistycznej Federacyjnej Republiki Jugosławii, był zdeterminowany potrzebą zachowania spokoju w regionie. Obawiano się eskalacji działań wojennych i „rozlania” konfliktu na inne państwa regionu, stąd usiłowano doprowadzić do szybkiego zakończenia działań zbrojnych. Jednym z podmiotów działających na rzecz bezpieczeństwa i ustabilizowania sytuacji na Bałkanach była Europejska Wspólnota Gospodarcza (od 1992 roku Unia Europejska). Nieskuteczność tych zabiegów w początkowej fazie konfliktu jugosłowiańskiego zmusiła Wspólnotę Europejską do poszukiwania innych form wsparcia dla regionu.

Kształtowana przez lata strategia działania na rzecz państw pojugosłowiańskich obecnie zawiera konkretne instrumenty oddziaływania, jednym z nich jest perspektywa rozszerzenia UE o państwa, które sprostają warunkom akcesji. Unijna polityka wobec regionu przyjęła postać pakietu działań wobec tak zwanych Bałkanów Zachodnich ${ }^{10}$, czyli państw powstałych po rozpadzie b. Jugosławii (za wyjątkiem Słowenii ${ }^{11}$ ) oraz Albanii.

W niniejszym artykule przedmiotem zainteresowania będą tylko państwa powstałe w wyniku rozpadu federacji jugosłowiańskiej, obecnie pretendujące do uzyskania członkostwa w Unii Europejskiej. Przyjęta unijna strategia działania i stosowane instrumenty - stanowiące pochodną procesu stabilizacji i stowarzyszenia - sąjednakowe

9 Wniosek o zbadanie sprawy Kosowa przez MTS został złożony w październiku 2008 r. przez Zgromadzenie Ogólne ONZ na wniosek Serbii. Wprawdzie opinia ta ma charakter doradczy, jednakże państwa przeciwne niepodległości Kosowa twierdziły, iż może ona spowodować niebezpieczny precedens. Zob. Sukces Serbii w Zgromadzeniu Ogólnym ONZ, „Best OSW”, 16 X 2008.

10 Bałkany Zachodnie zostały wyodrębnione sztucznie na potrzeby prowadzonej przez UE polityki wobec części państw Europy Południowo-Wschodniej. UE określa tym mianem wszystkie poza Słowenią państwa powstałe po rozpadzie b. Jugosławii (Bośnię i Hercegowinę, Chorwację, Czarnogórę, Byłą Jugosłowiańską Republikę Macedonii, Serbię i Kosowo w rozumieniu rezolucji Rady Bezpieczeństwa ONZ nr 1244/99) oraz Albanię. Zob. K. Koźbiał, Unia Europejska jako czynnik stabilizacyjny na Bałkanach. Stan obecny i wyzwania na przyszłość, w: Unia Europejska jako współczesny aktor stosunków międzynarodowych, red. J. Knopka, Toruń 2009, s. 369.

11 W przypadku Słowenii zarówno niepodległość, jak i późniejszy proces przeobrażeń politycznych i gospodarczych był najmniej problematyczny. Po zakończeniu tzw. wojny dziesięciodniowej niepodległość tego kraju została przesądzona i w następnych latach państwo stopniowo budowało swój potencjał polityczny i ekonomiczny w regionie. Zaowocowało to wejściem Słowenii do UE 1 maja 2004 roku. Szerzej na temat: E. Bujwid-Kurek, Państwa pojugosławiańskie..., s. 67-87; P. Mikuli, Parlament Stowenii, Warszawa 2003; P. Mikuli, System konstytucyjny Stowenii, Warszawa 2004; J. Wojnicki, Droga Europy Środkowo-Wschodniej do Unii Europejskiej (Czechy, Stowacja, Stowenia, Wegry), Warszawa 2007; J. Wojnicki, Przeobrażenia ustrojowe..., s. 49 i n.; J. J. Wiatr, Stowenia przykład udanej transformacji, Warszawa 1998; A. Orzelska, Słowenia - pięć lat w Unii Europejskiej, w: Pierwsza pięciolatka. Małe państwa Europy Środkowo-Wschodniej w Unii Europejskiej, red. R. Żelichowski, Warszawa 2010, s. 159-175. 
dla wszystkich państw, w związku z czym muszą one spełnić takie same kryteria. Zarazem jednak postęp w zakresie polityki rozszerzenia ma charakter warunkowy. Każde z państw oceniane jest odrębnie, przy czym od oceny sytuacji w zakresie wprowadzania unijnych wymogów uzależnione jest dalsze wsparcie Unii i przybliżenie perspektywy członkostwa w UE - priorytetu deklarowanego przez wszystkie państwa bałkańskie.

\section{Uwarunkowania polityki Unii Europejskiej wobec państw pojugosłowiańskich}

Współcześnie geopolityczny układ stosunków w Europie Południowo-Wschodniej stanowi konsekwencję wydarzeń, które rozgrywały się od początku lat dziewięćdziesiątych XX wieku. Decyzje parlamentów chorwackiego i słoweńskiego były początkiem demontażu SFRJ, co z kolei stanowiło swoiste dopełnienie tłumionych przez lata konfliktów politycznych, religijnych i narodowościowych na terytorium państwa jugosłowiańskiego. Należy jednak podkreślić, że decyzje te jedynie uruchomiły nieuchronny proces dezintegracji SFRJ, wyzwalając podobne dążenia w pozostałych częściach federacji. Przez lata dążenia te skutecznie hamował Tito - Josip Broz, i prowadzona przez niego polityka, wspierana przez Związek Komunistów Jugosławii (ZKJ) i armię jugosłowiańską. Jego śmierć, a także coraz wyraźniejsze rozbieżności w interesach poszczególnych republik i ich liderów politycznych, spowodowały wzrost narodowościowych sporów, nasilenie problemów ekonomicznych. Zmiany w Europie Środkowej i Wschodniej wzmocniły tendencje separatystyczne poszczególnych republik. O ile proces rozpadu wydawał się być nieuchronny, o tyle sposób dekompozycji państwa jugosłowiańskiego mógł być kontrolowany i przebiegać znacznie łagodniej. Zróżnicowane motywacje poszczególnych uczestników tego procesu, a także przyjęta przez społeczność międzynarodową linia postępowania wobec regionu bałkańskiego spowodowały, że proces ten toczył się przez dłuższy czas samoistnie, pod dyktando partykularnych interesów poszczególnych republik i ich liderów.

Działania wojenne, które stopniowo obejmowały kolejne terytoria SFRJ, początkowo rozgrywały się przy minimalnym zaangażowaniu społeczności międzynarodowej. $\mathrm{Na}$ początku lat dziewięćdziesiątych kryzys jugosłowiański traktowano jako wewnętrzny problem Jugosławii. Sądzono, że zostanie on samoistnie rozwiązany, przy uwzględnieniu interesów i potrzeb wszystkich zaangażowanych w konflikt stron. Dla niektórych ogłoszenie niepodległości przez Słowenię i Chorwację było początkiem procesu upadku systemu komunistycznego w Jugosławii. Wydarzenia na Bałkanach wpisywano w ciąg zdarzeń związanych z załamaniem się zimnowojennego ładu. Niewielu wówczas zakładało, iż niepodległość Serbii i Czarnogóry doprowadzi do rozpadu Jugosławii, i że będą temu towarzyszyć krwawe działania wojenne. Oczekiwano raczej, że deklaracje o niepodległości będą impulsem do głębokiej przebudowy ustroju i demokratyzowania państwa, a nie do jego upadku.

Narastające od śmierci Tita problemy polityczne, społeczne i ekonomiczne, przy silnych aspiracjach niepodległościowych poszczególnych republik doprowadziły jednak do secesji Słowenii i Chorwacji, co potwierdziło dezintegrację Jugosławii. Wydarzenia na Bałkanach zaskoczyły świat i Europę. Początkowo brakowało zdecydowanych 
działań ze strony organizacji międzynarodowych i głównych mocarstw. Z dzisiejszej perspektywy można stwierdzić, że pokładano zbyt duże nadzieje, że strony konfliktu same doprowadzą do jego zakończenia. Europa i świat pochłonięte były innymi problemami, pozostawiły więc tę część Europy samą sobie.

Krwawy demontaż SFRJ wykazał, że brakuje determinacji w działaniach organizacji międzynarodowych, brakuje im umiejętności przewidywania konsekwencji podejmowanych decyzji, świadczył też o tym, że państwa kierują się przede wszystkim partykularnym interesem, a wspólnota międzynarodowa jest bezczynna ${ }^{12}$. Niekorzystnie również wypadła Europejska Wspólnota Gospodarcza (Unia Europejska). Nieskuteczność prowadzonych działań, co wynikało głównie z braku jednolitej polityki ówczesnych państw członkowskich, a także przeciwstawnych interesów, spowodowało, że Wspólnota Europejska przez dłuższy czas nie była w stanie samodzielnie i skutecznie interweniować na europejskim podwórku. Posiadane wówczas zasoby i instrumenty były niewystarczające, a perspektywy budowy wspólnej polityki zagranicznej i bezpieczeństwa w sytuacji niezdolności państw członkowskich do przyjęcia spójnego i wspólnego stanowiska były odległe ${ }^{13}$. To wszystko doprowadziło do kilkuletniej wojny, w której rozbrzmiewały spory narodowościowe, religijne, kulturowe ${ }^{14}$.

$\mathrm{Na}$ początku lat dziewięćdziesiątych XX wieku kluczową rolę w kwestii jugosłowiańskiej odgrywały najważniejsze państwa ówczesnej EWG - Republika Federalna Niemiec, Francja, Wielka Brytania, Włochy. Każde z nich reprezentowało jednak odmienny pogląd na temat przyszłości Jugosławii, co skutkowało brakiem jednolitego stanowiska tej organizacji ${ }^{15}$. Reakcje tych państw w początkowym stadium kryzysu jugosłowiańskiego uzależnione były od ich interesów w regionie i to one decydowały o postawie i przychylności wobec którejś ze stron konfliktu. I tak wsparcie otrzymywali zarówno zwolennicy secesji, jak i obrońcy federacji jugosłowiańskiej, co z kolei zaostrzało konflikt.

12 Tadeusz Mazowiecki - sprawozdawca Komisji Praw Człowieka ONZ ds. konfliktu w byłej Jugosławii - apelował do opinii publicznej, informując ją o aktach ludobójstwa. W roku 1995, protestując przeciw bierności społeczności międzynarodowej, złożył dymisję. Zob. Raporty Tadeusza Mazowieckiego z byłej Jugosławii, Poznań-Warszawa 1993.

13 Zob. R. Zięba, Unia Europejska jako aktor stosunków międzynarodowych, Warszawa 2003, s. 169; A. Orzelska, Polska polityka zagraniczna wobec rozbieżności w stosunkach transatlantyckich na tle konfliktów w bytej Jugosławii, ,Studia Polityczne” 2009, nr 24, s. 229-230; P. Żurawski vel Grajewski, Upokorzona Europa, w: Świat po Kosowie, red. A. Magdziak-Miszewska, Warszawa 2000, s. 66.

${ }^{14}$ Krzysztof Malinowski zwraca uwagę, że jedną z podstawowych przeszkód w odegraniu kluczowej roli przez WE w początkowym stadium konfliktu była mniejsza czy większa inercja zachodnioeuropejskich sojuszników, opóźniająca zaaprobowanie użycia siły w celach niezwiązanych bezpośrednio z obroną własnych interesów narodowych i sojuszniczego terytorium. Ponadto wskazuje, iż interpretowanie konfliktu jugosłowiańskiego w kategoriach partykularno-historycznych rzutowało na zróżnicowane preferencje mocarstw. Zob. K. Malinowski, Przemiany niemieckiej polityki bezpieczeństwa 1990-2005, Poznań 2009, s. 307-309.

${ }_{15}$ Wskazuje na to M. Waldenberg, Rozbicie Jugosławii..., s. 86. Zob. także K. Malinowski, Przemiany niemieckiej polityki..., s. 309-323; A. Orzelska, Polska polityka zagraniczna wobec rozbieżności w stosunkach transatlantyckich na tle konfliktów w bytej Jugostawii, „Studia Polityczne” 2009, nr 24, s. 217-229. 
Wysiłki Wspólnoty Europejskiej - oferowanie pomocy ekonomicznej, próby mediacji, udzielanie i organizowanie wsparcia humanitarnego, wprowadzenie sankcji ekonomicznych oraz embarga na dostawy broni do Jugosławii, kolejne propozycje pokojowe - okazały się również niewystarczające ${ }^{16}$. Fiasko wspólnotowej polityki zobligowało UE do poszukiwania nowych, skuteczniejszych form oddziaływania.

Po zawarciu porozumienia pokojowego w Dayton (1995 rok) Unia Europejska sformułowała założenia swojej polityki wobec Bałkanów Zachodnich, deklarując zaangażowanie w odbudowę regionu, działania na rzecz przezwyciężania napięć i konfliktów oraz włączenie tego obszaru w europejskie procesy integracyjne. W kolejnych latach Unia systematycznie rozwijała relacje z państwami bałkańskimi. Intensyfikując swe kontakty oparte na opracowanych w 1996 roku przez Radę do spraw Ogólnych wytycznych podejścia regionalnego, zmierzała do ustabilizowania sytuacji wewnętrznej w poszczególnych państwach regionu, ustanowienia i utrzymania demokracji oraz rządów prawa, zapewnienia poszanowania mniejszości narodowych i praw człowieka, wzmocnienia gospodarczego $\mathrm{w}$ regionie ${ }^{17}$. Wspierając przeobrażenia polityczno-ustrojowe oraz ekonomiczne regionu, Unia Europejska dążyła do ustabilizowania sytuacji, stworzenia warunków do pokojowego współistnienia narodów bałkańskich, a tym samym do wyeliminowania przyczyn konfliktów ${ }^{18}$.

W powszechnym odczuciu włączenie obszaru bałkańskiego do zintegrowanej części kontynentu europejskiego miało zwiększyć szanse na rozwój tej części Europy i jej dalszą pokojową egzystencję. Zaangażowanie UE wynikało również z przeświadczenia o istnieniu zależności między bezpieczeństwem w regionie a bezpieczeństwem całej Europy. Stąd też jej uwaga była skupiona na poszukiwaniu skutecznych instrumentów oddziaływania na ten region.

Pomimo że wsparcie dla procesu transformacji i odbudowy państw pojugosłowiańskich było sukcesywnie wzmacniane, początkowo nie przynosiło spodziewanych rezultatów. Nieskuteczność stosowanych instrumentów, głównie mediacji oraz pomocy humanitarnej, wydarzenia w Kosowie w 1999 roku oraz stopniowa redukcja zaangażowania USA i NATO na Bałkanach spowodowały konieczność wypracowania nowych rozwiązan ${ }^{19}$. Zdecydowano się więc prowadzić wielosektorową politykę wobec tego regionu, podejmując jednocześnie działania o politycznym, ekonomicznym i militarnym charakterze. Wyrazem dążeń UE było przyjęcie w czerwcu 1999 roku Paktu stabilności dla Europy Poludniowo-Wschodniej, a następnie rozpoczęcie procesu sta-

16 Szerzej o inicjatywach EWG (później UE): A. Orzelska, Wpływ konfliktu w byłej Jugosławii na stosunki między Stanami Zjednoczonymi a Uniq Europejska 1990-1995, Warszawa 2004, s. 39 i n.; A. Paterek, Polityka Unii Europejskiej wobec Batkanów Zachodnich, w: Czynniki stabilizacji i destabilizacji w stosunkach międzynarodowych na poczatku XXI wieku, red. I. Stawowa-Kawka, Kraków 2009, s. 305-320; R. Zięba, Unia Europejska..., s. 165-171.

${ }_{17}$ B. Górka-Winter, Polityka zewnętrzna Unii Europejskiej wobec Bałkanów Zachodnich - wniosek Chorwacji o przystapienie do UE, „Biuletyn”, PISM 2003, nr 36, s. 1-2.

18 D. Wybranowski, Unia Europejska i jej instytucje jako narzędzia wspierania procesu demokratyzacji w wybranych krajach Bałkanów Zachodnich, w: Unia Europejska jako współczesny aktor stosunków międzynarodowych, red. J. Knopek, Torun 2009, s. 350-351.

19 B. Górka-Winter, Polityka zewnętrzna Unii Europejskiej wobec Bałkanów Zachodnich - wniosek Chorwacji o przystapienie do UE, „Biuletyn”, PISM 2003, nr 36, s. 1. 
bilizacji i stowarzyszenia (SAP), który został zainicjowany w Zagrzebiu w 2000 roku $^{20}$. Głównym celem tego procesu było przystąpienie krajów bałkańskich do UE pod warunkiem spełnienia określonych wymogów, w tym kryteriów kopenhaskich ${ }^{21}$. Państwa bałkańskie zobowiązały się do rozwoju stosunków międzysąsiedzkich, respektowania praw mniejszości, współpracy z Międzynarodowym Trybunałem Karnym ds. Zbrodni w b. Jugosławii, zwiększenia kontroli nad handlem bronią, unormowania sytuacji prawnej żeglugi na Dunaju, a nadto przeprowadzenia reform gospodarczych ${ }^{22}$. Założenia te zmodyfikowano podczas szczytu UE-Bałkany Zachodnie w Salonikach, w czerwcu 2003 roku. W roku 2005 Komisja Europejska przyjęła z kolei tak zwaną mapę drogową dla Bałkanów Zachodnich, określając etapy integracji z UE. W kolejnych latach UE potwierdzała wolę intensyfikacji współpracy z Bałkanami Zachodnimi, precyzując zarazem katalog instrumentów oddziaływania wobec tego regionu i formułując warunki, którym muszą sprostać poszczególne państwa ${ }^{23}$. Podczas spotkania wszystkich ministrów spraw zagranicznych państw UE oraz ministrów spraw zagranicznych Bałkanów Zachodnich w Salzburgu, w marcu 2006 roku, powtórzono, że przyszłość Bałkanów leży wewnątrz ugrupowania europejskiego. Jednocześnie unijni ministrowie wezwali do wzmocnienia współpracy regionalnej między państwami bałkańskimi. Uznano, iż szansą zażegnania konfliktów jest wzrost dobrobytu poszczególnych państw i społeczeństw, upowszechnienie wartości demokratycznych, praw człowieka i wolności obywatelskich. Sposobem osiagnięcia tych celów jest bliższe powiązanie regionu z obszarem UE przez nawiązanie współpracy politycznej i gospodarczej, a w perspektywie - włączenie w unijne struktury ${ }^{24}$. W kolejnych latach instytucje unijne wielokrotnie potwierdzały gotowość przyjęcia państw bałkańskich pod warunkiem wywiązania się z przyjętych zobowiązań - dostosowania systemu politycznego, prawnego, gospodarczego do stawianych przez Wspólnotę Europejską wymogów, a nadto prowadzenia dialogu w regionie. W konkluzjach ze szczytu Rady Europy z 14 grudnia 2007 roku w Brukseli znalazła się uwaga, iż przyszłość Bałkanów Zachodnich leży w Unii Europejskiej ${ }^{25}$. Ponownie zadeklarowano gotowość do kontynuacji debaty na temat potencjalnego członkostwa państw pojugosłowiańskich w UE,

${ }^{20}$ Bałkany Zachodnie a integracja europejska. Perspektywy i implikacje, red. R. Sadowski, J. Muś, Warszawa 2008, s. 8-15.

21 J. Wojnicki, Dylematy integracyjne państw pojugosłowiańskich, w: Unia Europejska i Polska wobec dylematów integracyjnych na poczatku XXI wieku, red. M. Stolarczyk, Toruń 2006, s. 329-330.

22 P. Borkowski, Polityka sqsiedztwa Unii Europejskiej, Warszawa 2009, s. 75-76.

23 Zob. Batkany Zachodnie a integracja europejska..., s. 10-17; M. Fiszer, Polityka rozszerzeniowa, http://eup.wse.krakow.pl/?page_id=121; EU Enlargement Strategy and Main Challenges 2006-2007 (including annexed special report on the EU's capacity to integrate new members), http://ec.europa.eu/enlargement/pdf/key_documents/2006/nov/com_649_strategy_paper_pl.pdf; Bałkany Zachodnie na drodze do UE: umacnianie stabilności i dobrobytu, http://eur-lex.europa.eu/LexUriServ/ LexUriServ.do?uri=COM:2006:0027:FIN:PL:DOC; Komunikat Komisji dla Parlamentu Europejskiego i Rady, Bałkany Zachodnie: wzmocnienie perspektywy europejskiej, http://eur-lex.europa.eu/Notice.do?val=466377:cs\&lang=pl\&list=491190:cs,489898:cs,489897:cs,489629:cs,480574:cs, 478229:cs,476892:cs,466377:cs,466774:cs,490639:cs,\&pos=8\&page=1\&nbl=607\&pgs=10\&hwords= \&checktexte $=$ checkbox \&visu $=\#$ texte.

24 W. Manteuffel, Batkany Zachodnie w drodze do UE, http://www.pe24.pl/tekst-3800/Wladyslaw-Manteuffel-Balkany-Zachodnie-w-drodze-do-UE.

${ }_{25}$ Konkluzje prezydencji, Bruksela, 14 XII 2007, http://prezydencjaue.gov.pl/files/por.pdf. 
uzależniając tempo akcesji od podejmowanych przez te państwa wysiłków w zakresie wdrażania niezbędnych reform. W lutym 2008 roku Rada Europy ponownie zapewniła o swoim zaangażowaniu na rzecz włączenia państw bałkańskich w europejską perspektywę. Ponadto wezwała Komisję Europejską do wykorzystywania instrumentów wspólnotowych do promowania rozwoju gospodarczego i politycznego oraz udostępnienia całemu regionowi konkretnych środków, które to ułatwią ${ }^{26}$. Podobne stwierdzenia padły również na forum kolejnej prezydencji Rady Europy w czerwcu 2008 roku ${ }^{27}$. Równie pozytywnie o zbliżeniu Bałkanów Zachodnich do UE wypowiadała się Rada ds. Ogólnych i Stosunków Zewnętrznych w grudniu 2007 oraz 2008 roku. O tym, że przyszłość Bałkanów Zachodnich leży w UE wspomniano także w komunikacie Komisji Europejskiej do Parlamentu Europejskiego w marcu 2008 roku $^{28}$. W oświadczeniu z Brdo - Nowe spojrzenie na Bałkany Zachodnie - podkreślono z kolei potrzebę nadania nowego impulsu agendzie z Salonik i deklaracji salzburskiej ${ }^{29}$. O potrzebie intensyfikacji działań na rzecz stabilizacji na Bałkanach wypowiedział się również Parlament Europejski. W kwietniu 2009 roku przyjął on rezolucję w sprawie umacniania stabilności i dobrobytu na Bałkanach Zachodnich ${ }^{30}$.

Obserwując i analizując postępy poszczególnych państw regionu Bałkanów Zachodnich oraz oceniając stopień wypełniania narzuconych wymogów, Unia Europejska cały czas nie wyklucza możliwości ich integracji ze Wspólnotą. Na unijnym forum pojawiają się twierdzenia, że niewystarczające tempo reform nie dyskwalifikuje żadnego z państw, a stanowi zachętę do wzmocnienia wysiłków.

Wśród państw członkowskich panuje consensus w sprawie rozszerzenia UE o kraje bałkańskie. Państwa te, w tym również Polska, traktują tę kwestię jako najważniejszy czynnik stabilizujący sytuację w tej części Europy. Odmienne uwarunkowania geograficzne, polityczne, gospodarcze i historyczne powodująjednak, że są pewne rozbieżności w stanowiskach poszczególnych państw członkowskich ${ }^{31}$, szczególnie jeśli chodzi o warunki, jakie muszą spełnić państwa pojugosłowiańskie, by można było mówić o pełnej integracji.

${ }^{26}$ Komunikat Komisji dla Parlamentu Europejskiego i Rady: Bałkany Zachodnie: wzmocnienie perspektywy europejskiej, http://eur-lex.europa.eu/LexUriServ/LexUriServ.do?uri=COM:2008: 0127:FIN:PL:HTML.

27 Konkluzje prezydencji, Bruksela, 20 VI 2008, http://www.cie.gov.pl/WWW/dok.nsf/ 0/92BAEEDBCBA7AE77C1256E9A0033DC66?Open\&RestrictToCategory=.

${ }^{28}$ Komunikat Komisji dla Parlamentu Europejskiego i Rady: Bałkany Zachodnie: wzmocnienie perspektywy europejskiej, http://eur-lex.europa.eu/LexUriServ/LexUriServ.do?uri=COM:2008: 0127:FIN:PL:HTML.

${ }^{29}$ Oświadczenie dotyczące zaangażowania Unii Europejskiej na Bałkanach Zachodnich przyjęto podczas nieformalnego spotkania ministrów spraw zagranicznych w Brdo 28-29 marca 2008 r. Spotkanie zorganizowane zostało podczas słoweńskiej prezydencji, dla której kwestia integracji państw obszaru pojugosłowiańskiego z UE była jednym z priorytetów. Zob. Program prezydencji Stoweńskiej, http://www.cie.gov.pl/HLP/files.nsf/0/4E9E347D5D14BA44C12573F7004016C7/\$file/Slowenska_prezydencja.doc; B. Wojna, Prezydencja Stowenii w Unii Europejskiej, „Biuletyn”, PISM 2008, nr 1, s. 1-2.

${ }^{30}$ Rezolucja Parlamentu Europejskiego z dnia 24 kwietnia 2009 r. w sprawie umacniania stabilności i dobrobytu na Bałkanach Zachodnich, (2010) C 184 E/21), http://eur-lex.europa.eu/LexUriServ/ LexUriServ.do?uri=OJ:C:2010:184E:0100:0106:PL:PDF.

31 Szerzej na ten temat Bałkany Zachodnie a integracja europejska..., s. 17-22. 


\section{Współczesne determinanty rozszerzenia UE o kraje pojugosłowiańskie}

Na obszarze pojugosłowiańskim wciąż, pomimo upływu wielu lat od zakończenia działań wojennych, zawarcia porozumienia z Deyton, upadku reżimu Slobodana Miloševicia, sytuacja jest daleka od pożądanej przez społeczność międzynarodową ${ }^{32}$. Wizja członkostwa w UE miała stanowić silną zachętę do reform politycznych i gospodarczych, a tym samym wzmocnić poziom bezpieczeństwa i stabilności w Europie. Uznano, że możliwość członkostwa zobliguje także państwa pojugosłowiańskie do uregulowania stosunków bilateralnych, do poszukiwania sposobów na polubowne zakończenie sporów, do unikania sytuacji, które potęgowałyby kryzys. Gwarancję stabilności w regionie miała stanowić poprawa sytuacji gospodarczej państw, a wraz z nią wzrost poziomu życia obywateli po wejściu w struktury unijne.

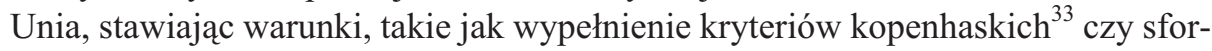
mułowane w ramach procesu stabilizacji i stowarzyszenia konieczność podjęcia dialogu politycznego z UE, współpraca z międzynarodowym wymiarem sprawiedliwości w obszarze sprawiedliwości i bezpieczeństwa, współpraca gospodarcza oraz współpraca regionalna ${ }^{34}$, chciała doprowadzić do samodzielnego rozwoju państw pojugosławiańskich $^{35}$. Sformułowane przez UE warunki zbliżenia ze wspólnotami europejskimi są dla części państw tego obszaru początkiem bardzo długiej drogi - ich perspektywa wejścia jest odległa. Wynika to ze zróżnicowanego tempa wprowadzania reform, natężenia problemów politycznych i gospodarczych, stanu stosunków sąsiedzkich, wywiązywania się ze zobowiązań wobec wspólnoty międzynarodowej (na przykład rozliczenie zbrodni wojennych) $)^{36}$. Państwa pojugosłowiańskie członkostwo w UE traktują jako cel strategiczny swojej polityki, oczywiste jest dla nich, że włączenie ich do obszaru wspólnotowego będzie siłą napędową i gwarantem stabilności w Europie Południowo-Wschodniej.

Obecnie kraje pojugosłowiańskie można podzielić na dwie kategorie (z uwagi na stan zaawansowania rokowań z UE), a mianowicie na kraje kandydujące (Chorwacja,

32 J. Bokajło, Regionalizacja i europeizacja Bałkanów Zachodnich, w: Regionalizacja w stosunkach międzynarodowych. Aspekty polityczno-gospodarcze, red. K. Jędrzejczyk-Kulniak, L. Kwieciński, B. Michalski, E. Stadtmüller, Torun 2008, s. 362.

33 Kryteria kopenhaskie uzgodniono podczas posiedzenia Rady Europejskiej w Kopenhadze w czerwcu 1993 r. Dotyczą one: stabilności instytucji demokratycznych, praworządności, poszanowania praw człowieka, ochrony mniejszości narodowych, funkcjonowania gospodarki rynkowej, gotowości do sprostania warunkom konkurencji UE, zdolności do wypełniania obowiązków wynikających z członkostwa, przyjęcia dorobku prawnego Unii Europejskiej (tzw. acquis communautaire). Zob. J. Ruszkowski, E. Górnicz, M. Żurek, Leksykon integracji europejskiej, Warszawa 2002, s. 154.

34 Bałkany Zachodnie a integracja europejska..., s. 15-16.

35 Ł. Bartkowiak, Unia Europejska wobec Batkanów Zachodnich i Turcji, „Przegląd Zachodni” 2006, $\mathrm{nr} 4$.

${ }^{36}$ Zob. Ł. Kobeszko, Bałkany Zachodnie idq $w$ dobrym kierunku, http://www.psz.pl/ tekst-18151/Balkany-Zachodnie-ida-w-dobrym-kierunku; Kraje na drodze do czlonkostwa w UE, http://ec.europa.eu/enlargement/the-policy/countries-on-the-road-to-membership/index_pl.htm; Perspektywy rozszerzenia UE, http://ec.europa.eu/news/external_relations/081105_1_pl.htm; M. Terlikowski, Relacje Unii Europejskiej z państwami Bałkanów Zachodnich - stan i perspektywy, „Biuletyn”, PISM 2008, nr 12. 
Była Jugosłowiańska Republika Macedonii) i kraje potencjalnie kandydujące (Bośnia i Hercegowina, Czarnogóra, Serbia, Kosowo w rozumieniu rezolucji Rady Bezpieczeństwa Narodów Zjednoczonych nr 1244). Unia Europejska, odnosząc się do postępów tych państw w zakresie wdrażania warunków członkostwa, pozytywnie ocenia zmiany, jakie nastąpiły w ciagu kilku ostatnich lat ${ }^{37}$. Docenia starania na rzecz utrzymania stabilności politycznej, systemu demokratycznego, przeobrażeń w gospodarce, stałego podnoszenia poziomu życia społeczeństw. Wyjątkiem wśród państw pojugosławiańskich jest Bośnia i Hercegowina, w której zakres przeobrażeń jest najmniej widoczny. Potwierdzeniem uznania przez UE wysiłków we wdrażaniu reform jest liberalizacja systemu wizowego dla Byłej Jugosłowiańskiej Republiki Macedonii, Czarnogóry i Serbii ${ }^{38}$, z kolei Parlament Europejski - 7 października 2010 roku - przyjął propozycję Komisji Europejskiej dotyczącą zniesienia przez państwa strefy Schengen obowiązku wizowego dla obywateli Albanii oraz Bośni i Hercegowiny. Do całkowitego zniesienia wiz jest jeszcze daleko, decyzję Parlamentu musi bowiem potwierdzić Rada Europejska (posiedzenie ma się odbyć w dniach 8-9 listopada 2010 roku), bardzo prawdopodobny jest jednak sprzeciw Francji ${ }^{39}$.

Obecnie Chorwacja znajduje się najbliżej członkostwa w UE. Od lat jest oceniana jako lider w regionie, państwo najszybciej i najsprawniej spełniające warunki akcesyjne. Jako pierwsza podpisała porozumienie SAA - już w 2001 roku (Macedonia w 2004, Czarnogóra w 2007, Serbia w 2008 i - jako ostatnia - Bośnia i Hercegowina w 2008) ${ }^{40}$. Pomimo kryzysu gospodarczego Chorwacja w większości obszarów objętych procesem integracji poczyniła największe postępy. Poinformowano o tym w październiku 2009 roku w raporcie publikowanym co roku o postępie w przygotowaniach do członkostwa w UE ${ }^{41}$. O sukcesach Chorwacji świadczyło także otwarcie - 30 czerwca 2010 roku - na międzyrządowej konferencji w Brukseli trzech ostatnich (z 35) rozdziałów negocjacyjnych: polityka konkurencji, sądownictwo i prawa podstawowe, polityka zagraniczna, bezpieczeństwa i obrony (20 jest już podpisanych $)^{42}$. Kilka dni wcześniej, 18 czerwca 2010 roku, prokurator generalny Międzynarodowego Trybunału Karnego dla byłej Jugosławii (ICTY) Serge Brammertz przedstawił Radzie Bezpieczeństwa ONZ raport dotyczący współpracy państw bałkańskich z trybunałem. Podkreślono w nim, że Chorwacja poprawiła współpracę z ICTY, choć nadal tematem trudnym

37 Communication from The Commission to The European Parliament and The Council. Enlargement Strategy and Main Challenges 2009-2010, Brussels, 14 X 2009, http://ec.europa.eu/enlargement/pdf/key_documents/2009/strategy_paper_2009_en.pdf.

38 Obywatele tych państw posiadający paszporty biometryczne od 19 grudnia 2009 r. mogą wjeżdżać bez wiz do Unii Europejskiej, maksymalnie na 90 dni. Od dłuższego czasu swobodą podróżowania na terytorium UE cieszą się obywatele Chorwacji.

39 Albania i BiH bliżej zniesienia wiz do strefy Schengen, „Best OWS” 2010, nr 34.

40 Kolejność podpisywania SAA nie decyduje o kolejności uzyskania członkostwa w UE. O ile przyszłość Chorwacji w UE jest przesądzona, o tyle już członkostwo Macedonii, która jako druga podpisała SAA, z uwagi na sprzeciw Grecji jest już niepewne.

${ }^{41}$ Croatia 2009 Progress Report accompanying the Communication from The Commission to The European Parliament and The Council. Enlargement Strategy and Main Challenges 2009-2010, COM (2009)533, Brussels, 14 X 2009, http://ec.europa.eu/enlargement/pdf/key_documents/2009/hr_rapport_2009_en.pdf.

${ }^{42}$ Chorwacja blizej zakończenia negocjacji akcesyjnych z UE, „Best OSW” 2010, nr 23. 
jest dostarczenie dokumentacji dotyczącej operacji „Burza” w Krajinie w 1995 roku, koniecznej do zakończenia procesu chorwackich generałów, między innymi Antego Gotoviny ${ }^{43}$.

Charakter relacji bilateralnych między Chorwacją a ościennymi republikami pojugosłowiańskimi ma dla Unii Europejskiej istotne znaczenie. W szczególności ważne są relacje Chorwacji z Serbią, które przez lata zdominowane były przez próby rozliczenia zbrodni wojennych. W maju 2008 roku Chorwacja zdecydowała się na oskarżenie Serbii o zbrodnie wojenne przed Międzynarodowym Trybunałem Sprawiedliwości (MTS ${ }^{44}$. Serbia złożyła również pozew do MTS w sprawie zbrodni wojennych popełnionych przez Chorwację na serbskich obywatelach w trakcie wojny w Jugosławii ${ }^{45}$. Wzajemnym relacjom nie pomogło również uznanie przez Chorwację niepodległości Kosowa w marcu 2008 roku. Nie służyły temu również publiczne wystąpienia polityków, którzy, podgrzewając atmosferę radykalnymi opiniami, utrudniali ustabilizowanie wzajemnych relacji. Przykładem może być wypowiedź Stipe Mesicia, kończącego kadencję prezydenta Chorwacji, ze stycznia 2010 roku. Skrytykował on Republikę Serbską w Bośni i Hercegowinie oraz politykę Belgradu wobec Kosowa ${ }^{46}$.

Warto jednak zwrócić uwagę, że oba kraje próbują rozwijać kontakty zarówno polityczne, jak i gospodarcze ${ }^{47}$. Świadczy o tym chociażby deklaracja prezydentów Serbii i Chorwacji z 24 marca 2010 o wycofaniu z MTS wzajemnych oskarżeń o zbrodnie wojenne i rozwiązania sporu na płaszczyźnie bilateralnej ${ }^{48}$. Poprawa relacji chorwacko-serbskich ma miejsce, gdyż prezydent Ivo Josipovič (wybrany pod koniec grudnia $2009 \mathrm{roku})$ reprezentuje nową koncepcję aktywnej polityki wobec regionu, która zakłada stworzenie przyjaznej atmosfery współpracy państw regionu i rozwiązanie spornych kwestii dotyczących przede wszystkim konsekwencji wojny na Bałkanach ${ }^{49}$.

Powodzenie europejskich aspiracji Chorwacji zależało również od definitywnego zakończenia sporu ze Słowenią. Przez lata kontrowersje dotyczące chorwacko-słoweńskiego sporu granicznego o rozgraniczenie wód Zalewu Pirańskiego ${ }^{50}$ rzutowały na tempo procesu integracji Chorwacji ze strukturami euroatlantyckimi. Ten niewielki, liczący niecałe $19 \mathrm{~km}^{2}$, akwen na północnym Adriatyku stanowi przedmiot konfliktu już od momentu uzyskania przez obydwa kraje niepodległości w 1991 roku. Od roku 2008 Słowenia blokowała na forum Rady Europejskiej negocjacje akcesyjne z Chorwacją, argumentując, iż w swoim stanowisku negocjacyjnym Zagrzeb przesądza o wyniku sporu granicznego ${ }^{51}$. Nadzieja na rozwiązanie sporu pojawiła się jesienią 2009 roku.

${ }^{43}$ Państwa bałkańskie coraz lepiej wspótpracuja z Trybunatem w Hadze, „Best OSW” 2010, nr 22.

44 Wzrost napięcia na linii Zagrzeb-Belgrad, „Best OSW” 2008, nr 19.

45 Zbliżenie w relacjach serbsko-chorwackich, „Best OSW” 2010, nr 13.

${ }^{46}$ K. Kubiak, Wojny i konflikty zbrojne i punkty zapalne na świecie, Warszawa 2007, s. 68; D. Smyrgała, Chorwacja, „Europa Środkowo-Wschodnia” 2008, s. 103.

${ }_{47}$ Chorwacja, Serbia i Stowenia zacieśniaja wspótpracę w transporcie kolejowym, „Best OSW” 2010, nr 26.

${ }_{48}$ Zbliżenie w relacjach serbsko-chorwackich, „Best OSW” 2010, nr 13.

49 Prezydent Chorwacji inicjuje nowa politykę wobec Bałkanów, „Best OSW” 2010, nr 15.

50 D. Smyrgała, Chorwacja, „Europa Srodkowo-Wschodnia” 2008, s. 99-104.

51 Ł. Kobeszko, Proces akcesyjny Chorwacji. Stan i perspektywy, http://www.psz.pl/ tekst-27022/Proces-akcesyjny-Chorwacji-Stan-i-perspektywy. 
W listopadzie premierzy obu krajów zawarli porozumienie, ustalono, że spór graniczny będzie rozwiązany przez arbitraż międzynarodowy. Decyzja ta została zatwierdzona przez parlamenty obu państw, Słowenia postanowiła jednak jeszcze poddać tę kwestię pod osąd społeczeństwa. W referendum, które przeprowadzono w czerwcu $2010 \mathrm{roku}$, Słoweńcy ostatecznie zgodzili się na międzynarodowy arbitraż. Wynik referendum wyraźnie świadczy o tym, że w społeczeństwie nadal są podzielone opinie, jednak otwiera on Chorwacji drogę do dalszych negocjacji z UE. W głosowaniu 51,5\% Słoweńców zadecydowało, że pozwolą na rozstrzygnięcie sporów granicznych z Chorwacją zewnętrznemu arbitrażowemu pracującemu pod egidą Unii Europejskiej ${ }^{52}$.

Podjęcie kroków w celu rozwiązania konfliktu granicznego dało podstawy do ponownego rozpoczęcia zablokowanych rozmów w sprawie akcesji Chorwacji. Wydaje się, że nic nie powinno już zahamować procesu integracji. W porównaniu z pozostałymi państwami pojugosłowiańskimi Chorwacja jest najbardziej zaawansowana na drodze do akcesji. Ponadto jest już członkiem wielu istotnych organizacji międzynarodowych, na przykład Rady Europy, OBWE, WTO, a od 2009 roku NATO, co umacnia jej pozycję w systemie stosunków międzynarodowych. Chorwacja prowadzi również ożywioną współpracę bilateralną zarówno z państwami regionu, jak i innymi. Na tle pozostałych państw w regionie jej sytuacja gospodarcza przez lata była stosunkowo stabilna. Negatywnie na chorwacką gospodarkę wpłynął światowy kryzys ekonomiczny, powodując znaczne obniżenie wszystkich wskaźników makroekonomicznych. Chorwacki rząd podjął jednak w 2009 roku środki mające na celu utrzymanie równowagi finansów publicznych ${ }^{53}$. Przed Chorwacją wydaje się, że zostało ostatnie zadanie - dopasowanie do wymogów UE polityki w obszarze konkurencji, sądownictwa i praw podstawowych oraz polityki zagranicznej, bezpieczeństwa i obrony. Chorwacja musi wzmóc wysiłki w zakresie zapewnienia rzeczywistej konkurencji, zakończyć dostosowanie prawa do dorobku prawnego UE oraz przyjąć uaktualniony krajowy program restrukturyzacji sektora stalowego, a nadto uwzględnić wymagania unijne dotyczące pomocy państwa dla tego sektora. W zakresie wymiaru sprawiedliwości i praw podstawowych zobligowano Chorwację do reformy sądownictwa, zapewnienia jego niezależności i profesjonalizmu, intensyfikacji działań na rzecz skuteczniejszej współpracy z Międzynarodowym Trybunałem Karnym dla b. Jugosławii, walki z korupcja, wzmocnienia ochrony mniejszości narodowych, rozstrzygnięcia kwestii powrotu uchodźców oraz poprawy ochrony praw człowieka. W przypadku polityki zagranicznej oraz polityki bezpieczeństwa i obrony UE zamierza analizować stan wdrażania rozwiązań w zakresie zwalczania nielegalnego gromadzenia i handlu bronią strzelecką, bronią lekką oraz amunicją ${ }^{54}$. Być może pewne niezadowolenie w strukturach unijnych wywoła nie-

52 M. Domagała, Chorwacja idzie do UE, 8 VI 2010, http://www.polskatimes.pl/fakty/ swiat/265999,chorwacja-idzie-do-ue,id,t.html; Bałkańska odwilż otwiera Chorwacji drzwi do UE, http://www.stosunkimiedzynarodowe.info/artykul,502,Balkanska_odwilz_otwiera_Chorwacji_drzwi_do_UE.

53 Informacje na temat sytuacji gospodarczej Chorwacji oraz podstawowych wskaźnikach ekonomicznych, http://www.msz.gov.pl/files/Informator\%20ekonomiczny\%20-\%20pdf/Chorwacja/Chorwacja\%2003.pdf; Ogólna charakterystyka sytuacji gospodarczej $w$ Chorwacji $w 2009$ r., http://www.zagrzeb.polemb.net/index.php?document $=31$.

54 Tenth meeting of the Accession Conference at Ministerial level with Croatia, Brussels, 30 June 2010, http://www.consilium.europa.eu/uedocs/cms_data/docs/pressdata/en/er/115569.pdf. 
chęć rządu chorwackiego do przeprowadzenia gruntownych reform ekonomicznych w związku z możliwością wzrostu deficytu z planowanych $2,5 \%$ do $4,2 \%$ PKB w 2010 roku, co wiązałoby się z koniecznością niekorzystnych dla społeczeństwa cięć budżetowych. Dotychczas rząd wprowadził daleko idące środki, które miały zahamować negatywne tendencje w gospodarce i ustabilizować sektor finansów publicznych. W obliczu przyszłorocznych wyborów wydaje się mało prawdopodobne, by obecny centroprawicowy rząd Jadranki Kosor podjął się kolejnych cięć w obawie przed opinią społeczną ${ }^{55}$.

Mimo istnienia trudności w wypełnianiu wszystkich warunków integracji, zwolennicy wstąpienia Chorwacji do UE wskazują rok 2012 jako możliwą datę rozszerzenia UE o kolejny po Słowenii kraj bałkański. Podstawowym argumentem jest znaczenie tego aktu dla całego regionu bałkańskiego. Przede wszystkim wpłynie to na wzrost bezpieczeństwa w regionie i będzie dobrym przykładem dla pozostałych państw, by intensyfikowały swoje wysiłki na rzecz reform. Odwlekanie daty przyjęcia Chorwacji mogłoby nieść ze sobą negatywne skutki. Pozostałe państwa bałkańskie, widząc nieskuteczność zabiegów Chorwacji, mogłyby stracić motywację do kontynuowania procesu wdrażania reform politycznych i gospodarczych, a to z pewnością wpłynęłoby negatywnie na proces stabilizacji $\mathrm{w}$ regionie. Pomimo to administracja unijna dość ostrożnie wypowiada się w kwestii rozszerzenia, twierdząc, iż w tej materii wiele zależy od samej Chorwacji i tempa jej reform ${ }^{56}$. O przyjęciu Chorwacji będzie decydować ogólny klimat dla kolejnego rozszerzenia UE. Istotne mogą się okazać opinie społeczeństwa na temat dalszego poszerzania granic Unii, na które na pewno duży wpływ będzie miała sytuacja ekonomiczna i możliwe konsekwencje finansowe z tytułu rozszerzenia. W przypadku Chorwacji, która sukcesywnie niweluje wszelkie sporne kwestie z sąsiadami i która ma ustabilizowaną sytuację wewnętrzną, nie istnieje ryzyko związane z przeniesieniem konfliktów na poziom europejski, co może pozytywnie wpłynąć na proces integracji Chorwacji z UE.

Odmiennym uwarunkowaniom podlega proces rozszerzenia UE o pozostałe państwa regionu. W przypadku Byłej Jugosłowiańskiej Republiki Macedonii (FYROM) przyszłość w UE rysuje mniej optymistycznie. Status kraju kandydującego Macedonia uzyskała w 2005 roku, jednak negocjacje akcesyjne nie zostały jeszcze podjęte. Podczas szczytu Unii Europejskiej, który odbył się 19-20 czerwca 2008 roku, zdecydowano, że warunkiem rozpoczęcia negocjacji akcesyjnych z Macedonią jest uregulowanie jej sporu z Grecją o nazwę ${ }^{57}$. W kolejnych miesiącach instytucje unijne formułowały pozytywne opinie na temat postępów Macedonii w realizowaniu unijnych postulatów. W raporcie Komisji Europejskiej z października 2009 roku pozytywnie oceniono starania FYROM, uznając, że kraj ten dostatecznie spełnia kryteria polityczne. Zwrócono uwagę na wypełnianie zobowiązań, w tym na realizację wytycznych umowy ramowej

55 Chorwacja unika reform przed wyborami, „Best OSW” 2010, nr 28.

${ }^{56}$ Chorwacja u drzwi Unii Europejskiej, http://www.euractiv.pl/rozszerzenie/artykul/chorwacja-u-drzwi-unii-europejskiej-001934.

57 Zob. Konflikt o nazwe Macedonii, „Best OSW” 2010, nr 22; Impas w integracji Macedonii z UE, „Best OSW” 2009, nr 43; R. Podgórzańska, Stosunki Polski z Macedonia, Przegląd Zachodni” 2009, nr 3, s. 115-116. 
z Ochrydy, która pozostaje istotnym elementem demokracji i rządów prawa w kraju. Wskazano na postępy w zakresie reformy administracji publicznej. Zauważono także niedostatki w zakresie walki z korupcją oraz w zakresie ochrony praw człowieka i mniejszości narodowych. W odniesieniu do kryteriów gospodarczych w opinii Komisji Była Jugosłowiańska Republika Macedonii stopniowo wypełnia postulaty unijne i zbliża swe rozwiązania do państw, w których funkcjonuje gospodarka rynkowa. Ogólnie zdaniem Komisji Była Jugosłowiańska Republika Macedonii poczyniła postępy w zakresie poprawy zdolności do przyjęcia zobowiązań wynikających z członkostwa, w szczególności w zakresie transportu, ceł i podatków oraz wymiaru sprawiedliwości, wolności i bezpieczeństwa. W mniejszym stopniu postęp został osiągnięty w niektórych innych dziedzinach, takich jak energia, środowisko naturalne, polityka społeczna i zatrudnienie ${ }^{58}$. Niestety, negocjacje akcesyjne nie mogły się rozpocząć z uwagi na wspomniany spór z Grecją i opór tego państwa wobec kontynuowania procesu akcesyjnego Macedonii ${ }^{59}$. W grudniu 2009 Rada Unii Europejskiej, mimo rekomendacji Komisji Europejskiej, nie zdecydowała się na rozpoczęcie negocjacji akcesyjnych z Macedonią.

Pojawiające się propozycje rozwiązania grecko-macedońskiego sporu, jeśli nie znajdą akceptacji obu stron, są skazane na niepowodzenie ${ }^{60}$. Zarówno macedońscy politycy, jak i opinia publiczna deklarują, że zachowanie nazwy państwa Republika Macedonii jest dla nich ważniejsze niż wejście w struktury euroatlantyckie ${ }^{61}$. Kwestie

58 Conclusions on the former Yugoslav Republik of Macedonia, http://ec.europa.eu/enlargement/pdf/key_documents/2009/conclusions_on_fyrom_en.pdf.

${ }_{59}$ W roku 2008 podczas szczytu w Bukareszcie z tego samego powodu zablokowała wejście Macedonii do NATO.

${ }^{60}$ Ze strony społeczności międzynarodowej padały różne propozycje nazwy tego państwa. Dla przykładu, w lutym 2008 ONZ zaproponowała pięć nowych nazw dla Macedonii: Demokratyczna Republika Macedonii, Konstytucyjna Republika Macedonii, Niezależna Republika Macedonii, Republika Górnej Macedonii, Republika Nowej Macedonii. W październiku 2008 mediator z ramienia ONZ - Matthew Nimetz zaproponował nazwę Republika Macedonii Północnej. W lipcu 2010 organizacja pozarządowa działająca na rzecz integracji Bałkanów Zachodnich - Europejska Inicjatywa Stabilizacyjna (ESI) zaproponowała dokonanie zmiany w konstytucji Macedonii i wprowadzenie zapisu o tym, że nowa, uzgodniona nazwa tego kraju, weszłaby w życie z dniem akcesji do UE. Pozwoliłoby to na odblokowanie negocjacji, Grecja zyskałyby bowiem gwarancję, że Macedonia nie wejdzie do UE jako Macedonia. W tym samym czasie prasa grecka proponowała nową nazwę -Republika Macedonii Wardaru (od nazwy największej rzeki w kraju). Zob. P. Codogni, Macedonia, „Europa Środkowo-Wschodnia" 2008, s. 285; ONZ proponuje dla Macedonii nazwe „,Macedonia Pótnocna”, za J. Pawlicki, Można pogodzić Grecję z Macedonia, „Gazeta Wyborcza”, 31 VII 2010; L. Podhorecki, Jugosławia. Dzieje narodów, państw i rozpad federacji, Warszawa 2000, s. 202-203; H. J. Sokalski, Odrobina prewencji. Dorobek dyplomacji prewencyjnej ONZ w Macedonii, Warszawa 2007, s. 84-87; J. Jackowicz, Macedonia, „Europa Środkowo-Wschodnia” 1993, s. 107; ONZ proponuje pięć nowych nazw dla Macedonii, http://www.rp.pl/artykul/96606,202483_ONZ_proponuje_dla_Macedonii_nazwe_Macedonia_Polnocna_html; http://wiadomosci.gazeta.pl/Wiadomosci/1,80614,4947812.html; M. Pietruszewski, Kontrowersje na temat tożsamości macedońskiej, http://www.psz.pl/tekst-11517/ Maciej-Pietruszewski-Kontrowersje-na-temat-tozsamosci-macedonskiej/Str-5; M. Szpala, Konflikt o nazwe Macedonii, Analizy OSW 2008, nr 22, http://osw.waw.pl/pub/BiuletynOSW/2008/0806/ 080625/best01.htm.

${ }^{61}$ Potwierdza to przeprowadzony w lipcu 2010 sondaż, w którym 66\% Macedończyków stwierdziło, iż utrzymanie nazwy Republika Macedonii jest ważniejsze niż euroatlantyckie sojusze. Chęć wstąpienia do UE i NATO wyraziło jedynie $26 \%$ respondentów. Zob. K. Krysieniel, J. Wojnicki, Par- 
integracji euroatlantyckiej zaczynają stanowić przedmiot konfliktu politycznego między rządzącym prawicowym gabinetem premiera Nikoły Grajewskiego a opozycją oskarżającą rząd o to, iż nie chce wejścia Macedonii do NATO i UE. Wydaje się zatem, że przy konsekwentnej postawie Macedończyków i Greków jedynie determinacja UE może doprowadzić do przyjęcia kompromisowego rozwiązania w sprawie nazwy państwa. Jednocześnie można postawić tezę, że przy braku politycznej woli całej UE wobec kolejnego rozszerzenia trwający grecko-macedoński spór jest „na rękę” samej UE, a wina za fiasko polityki rozszerzenia spadnie nie na UE, lecz na dwa zaangażowane w spór państwa - Grecję i Macedonię.

Pozostałe kraje pojugosłowiańskie należą do grona krajów potencjalnie kandydujących. UE konsekwentnie potwierdza możliwość ich wstąpienia, pod warunkiem spełnienia kryteriów akcesyjnych. Gesty te mają jednak raczej kurtuazyjny charakter. Wprawdzie UE deklaruje daleko posuniętą gotowość do rozszerzenia, jednak zdaje sobie sprawę z trudności, jakie się z tym wiążą. Złożona sytuacja wewnętrzna państw aspirujących do UE, problemy z transformacją ustrojowo-polityczna, trudna sytuacja gospodarcza, niskie tempo wprowadzania unijnych standardów i wypełniania międzynarodowych zobowiązań, a także trudności w relacjach bilateralnych w regionie hamują możliwość ich wstąpienia w europejskie struktury. Proces zbliżenia Serbii, Czarnogóry, Bośni i Hercegowiny czy w końcu Kosowa do Unii Europejskiej jest determinowany innymi przesłankami.

Serbia ma obecnie status kraju potencjalnie kandydującego do członkostwa w UE. Dotychczas zasadniczym powodem braku postępów w negocjacjach serbsko-unijnych była niewystarczająca - w ocenie Unii - współpraca Serbii z Międzynarodowym Trybunałem Karnym ds. Zbrodni w b. Jugosławii oraz kwestia statusu Kosowa i polityki serbskiej wobec tej prowincji. Przez długi czas rozmowy o integracji komplikował również fakt, iż należało je prowadzić dwutorowo - Serbia tworzyła wspólne państwo z Czarnogórą. Prace nad najważniejszym, podstawowym dla procesu integracji dokumentem - Porozumieniem o stabilizacji i stowarzyszeniu (SAA) - zakończono jesienią 2007 roku; parafowano je w Brukseli 7 listopada 2007 roku. Rząd serbski uczynił to jednak pod dużą presją ze strony UE. Rok później - 9 września 2008 roku - belgradzki parlament ratyfikował porozumienie. W tym czasie stosunki Serbii z UE zdominowała kwestia secesji Kosowa i uznania jego niepodległości przez znaczną część państw-członków UE oraz krytyczne stanowisko serbskie zarówno w sprawie secesji prowincji, jak i postawy poszczególnych państw UE w tej sprawie ${ }^{62}$. Pragnąc zachęcić Serbię do kontynuowania reform, zaproponowano wiele instrumentów wsparcia, wśród których zasadniczą rolę odegrały instrumenty finansowe ${ }^{63}$. Takim narzędziem było między

tie i systemy partyjne państw byłej Jugosławii, Pułtusk-Warszawa 2009, s. 134-136; Macedonia nie rwie się do Unii, http://www.rp.pl/artykul/13,509370-Macedonia-nie-rwie-sie-do-Unii.html.

62 Serbia zapowiadała ochłodzenie stosunków dyplomatycznych z tymi państwami, które uznały Kosowo, a także odwołała swoich ambasadorów w kilku stolicach, m.in. w Waszyngtonie, Paryżu i Ankarze. Zapowiadała początkowo odwołanie wszystkich ambasadorów z państw, które uznały niepodległość Kosowa, jednak z obawy przed międzynarodową izolacją wstrzymała się z tą decyzją. Zob. Pierwszy tydzień niepodległości Kosowa, „Best OSW” 2008, nr 9.

${ }^{63}$ We wrześniu 2009 r. przekazano dodatkową pomoc finansową w wysokości $100 \mathrm{mln}$ euro jako swoistą zachętę do kontynuowania procesu reform, mimo pogarszającej się sytuacji gospodarczej 
innymi tymczasowe porozumienie handlowe, w którym zastosowano wiele rozwiązań przyjętych w porozumieniu SAA. Konieczność przyjęcia tego dokumentu wynikała z tego, że Holandia zablokowała SAA, czego skutkiem było jego ostatecznie odrzucenie 15 września 2008 roku przez GAREC (Radę Unii Europejskiej ds. Ogólnych i Stosunków Zewnętrznych ${ }^{64}$. Rząd serbski wprowadził jednak jednostronnie zapisy tego porozumienia, sygnalizując swoje europejskie ambicje. Doceniając te starania, w połowie lipca 2009 roku Komisja Europejska zgodziła się na objęcie oprócz Macedonii i Czarnogóry także Serbii ruchem bezwizowym z państwami strefy Schengen. W roku 2009 prozachodni rząd Mirko Cvetkoviča sukcesywnie wdrażał zalecane przez UE reformy, zintensyfikowano również współpracę z Międzynarodowym Trybunałem Karnym ds. byłej Jugosławii. Polityka Serbii w stosunku do Kosowa uległa zmianie - stała się bardziej pragmatyczna, o czym świadczy podpisanie we wrześniu 2009 roku umowy między Ministerstwem Spraw Wewnętrznych Serbii a cywilną misją unijną w Kosowie (EULEX) ${ }^{65}$. Serbia podpisała (17 września 2009 roku) z UE także porozumienie o pomocy finansowej o wartości $100 \mathrm{mln}$ euro. Pomoc miała być przeznaczona na przygotowanie i wdrożenie ekonomicznych oraz legislacyjnych reform koniecznych do dalszej integracji, a także na sfinansowanie wydatków socjalnych, inwestycji infrastrukturalnych i subsydiów dla sektora budowlanego ${ }^{66}$. UE planowała uruchomić kolejne środki, warunkiem tego było jednak wypełnianie wymogów stawianych przez UE i Międzynarodowy Fundusz Walutowy.

Pomoc finansowa udzielana Serbii miała zdyskontować różnice stanowisk w odniesieniu do kwestii Kosowa, a także przekonać władze w Belgradzie i serbskie społeczeństwo o konieczności kontynuowania polityki „otwartych drzwi”. Dodatkowe wsparcie finansowe miało być dowodem na to, że UE traktuje Serbię priorytetowo i uznaje za strategicznego partnera na Bałkanach.

W październikowym raporcie (2009 rok) Komisji Europejskiej postępy Serbii w zakresie przygotowań do członkostwa w UE oceniono pozytywnie. Podkreślono, iż Serbia wykazuje zaangażowanie na rzecz integracji europejskiej, realizując postanowienia umowy przejściowej z UE, podjęła się przeprowadzenia najważniejszych reform politycznych, dążąc do spełnienia europejskich norm. Pozytywnie oceniono również trwałą współpracę Serbii z MTKJ. Jednocześnie zwrócono uwagę na potrzebę wzmocnienia zasady państwa prawa i przyspieszenia reform gospodarczych, a także przyjęcia konstruktywnej postawy wobec Kosowa ${ }^{67}$.

Serbii. Świadczyło to także o priorytetowej roli Serbii dla UE w procesie stabilizacji Bałkanów. Zob. Pomoc UE dla Serbii, „Best OSW” 2009, nr 32.

${ }^{64}$ Zarówno Holandia, jak i Belgia odmówiły stosowania SAA dopóki strona serbska nie doprowadzi do aresztowania generała Ratko Mladicia i nie przekaże go Międzynarodowemu Trybunałowi Karnemu ds. Zbrodni Wojennych. Zob. D. Smyrgała, Serbia, „Europa Środkowo-Wschodnia 2008”, s. 341.

65 Serbia zlożyla wniosek o czlonkostwo w UE, „Best OSW” 2010, nr 1.

66 Pomoc UE dla Serbii, „Best OSW” 2009, nr 32.

67 Serbia 2009 Progress Report accompanying The Comunnication from The Commission to the European Parliamnet and The Council. Enlargement Strategy and Main Challenges 2009-2010, COM (2009)533, http://ec.europa.eu/enlargement/pdf/key_documents/2009/sr_rapport_2009_en.pdf. 
7 grudnia 2009 ministrowie spraw zagranicznych państw UE wyrazili zgodę na wejście w życie od 1 stycznia 2010 roku umowy przejściowej dotyczącej handlu z Serbią, podpisanej wraz z Umowq o stabilizacji i stowarzyszeniu ${ }^{68}$. Wpłynęło to korzystnie na rozwój kontaktów unijno-serbskich, powodując wzrost determinacji Serbii w wypełnianiu zobowiązań.

22 grudnia 2009 roku w Sztokholmie Serbia złożyła oficjalny wniosek o członkostwo w UE. W czerwcu 2010 roku Rada UE podjęła decyzję o odblokowaniu ratyfikacji Porozumienia o stabilizacji i stowarzyszeniu z Serbią jednocześnie nie zdecydowała o przekazaniu wniosku akcesyjnego Serbii do Komisji Europejskiej. Odblokowanie umowy jest sygnałem poparcia serbskich starań i docenienia wysiłków modernizacyjnych, blokowanie zaś wniosku służy zaś zmuszeniu Serbii do kontynuowania wysiłków na rzecz integracji z UE ${ }^{69}$.

Można powiedzieć o polityce UE wobec Serbii, że jest zmienna. Unia z jednej strony oferuje wsparcie finansowe, ułatwienia wizowe, z drugiej wymusza zmianę polityki Serbii wobec Kosowa. U podstaw działania Unii niewątpliwie leży przeświadczenie, że bezpieczeństwo $\mathrm{w}$ regionie $\mathrm{w}$ dużym stopniu zależy od Serbii ${ }^{70}$. Stąd działania zmuszające Serbię do zmiany postawy wobec rządu w Kosowie, o czym świadczy uzgodniony wspólnie przez to państwo oraz państwa UE projekt rezolucji w sprawie Kosowa, którą 9 września 2010 roku jednomyślnie przyjęło Zgromadzenie Ogólne ONZ (założono w nim, że UE ma monitorować i nadzorować rozmowy między Belgradem a Prisztiną) ${ }^{71}$. Serbia, dla której priorytetem jest integracja z UE, musiała zrezygnować z konfrontacyjnej polityki wobec Kosowa. Należy jednak zakładać, że w dogodnym czasie powróci do kwestii statusu międzynarodowego Kosowa. Tym bardziej że w samej UE nie ma pełnej zgody co do jego położenia z punktu widzenia prawa międzynarodowego. Na razie Serbia ma jednak swoje małe zwycięstwo, 13 września 2010 roku Rada UE ds. Ogólnych zdecydowała, że w październiku przeanalizuje wniosek akcesyjny Serbii. Unijni ministrowie spraw zagranicznych 25 października 2010 roku w Luksemburgu zgodzili się na rozpatrzenie serbskiego wniosku o członkostwo w $\mathrm{UE}^{72}$. Prounijny kurs w polityce serbskiej przynosi konkretne wymierne sukce-

${ }_{68}$ UE odblokowuje umowe przejściowa z Serbia, „Best OSW” 2009, nr 42.

69 T. Żornaczuk, Rozpoczęcie procesu ratyfikacji Uktadu o stabilizacji i stowarzyszeniu z Serbia, „Biuletyn”, PISM 2010, nr 94, s. 1; UE odblokowuje ratyfikacje umowy stowarzyszeniowej z Serbia, „Best OSW” 2010, nr 21.

70 Swój sprzeciw wobec niepodległości Kosowa zamanifestowała, bojkotując udział w szczycie Bałkany Zachodnie-Unia Europejska w słoweńskim Brdzie w marcu 2010 r.

71 Wrześniowa rezolucja była konsekwencją złożonej przez Serbię odpowiedzi na niekorzystną dla niej opinię Międzynarodowego Trybunału Sprawiedliwości (MTS) z 22 lipca 2010 r. o legalności kosowskiej deklaracji niepodległości. Serbski rząd 28 lipca 2010 złożył w Zgromadzeniu Ogólnym ONZ samodzielny projekt rezolucji w sprawie Kosowa zawierający krytykę jednostronnego ogłoszenia niepodległości jako sposobu rozwiązania sporu oraz wzywał obie strony do rozpoczęcia dialogu. Działania Serbii skrytykowały zarówno UE, jak i USA. Naciski UE spowodowały przygotowanie wspólnego projektu, który został poparty przez wszystkie państwa UE, a w konsekwencji zaakceptowany przez Zgromadzenie Ogólne ONZ. Zob. Serbia pod presja Unii Europejskiej w sprawie Koso$w a$, ,Best OSW” 2010, nr 30.

${ }_{72}$ Ministrowie wyraźnie jednak zaznaczyli, iż postęp w negocjacjach będzie zależał od jednomyślnej oceny wszystkich państw, czy Serbia dobrze współpracuje z MTS w Hadze. Do tej pory niewystarczający zakres współpracy w ściganiu zbrodniarzy wojennych był głównym powodem ho- 
sy. Należy jednak zauważyć, że nie są proponowane żadne konkretne daty, wspomina się jedynie dość mgliście, że byłoby to możliwe około 2015 roku. Serbia mogłaby wejść w struktury unijne jako kolejny po Chorwacji kraj bałkański.

Pozostałe państwa pojugosłowiańskie również dążą do członkowstwa w Unii Europejskiej. Wyraźnie jednak się mówi, że zarówno Bośnia i Hercegowina, jak i Czarnogóra mają jeszcze sporo do nadrobienia ${ }^{73}$. Złożony przez Czarnogórę 15 grudnia 2008 roku wniosek o członkostwo został zablokowany na posiedzeniu Rady UE 14 lutego 2009 roku z powodu sprzeciwu kilku państw, między innymi Niemiec i Holandii, które uznały, że nie jest ten kraj dostatecznie przygotowany do członkostwa. Czarnogóra miała duże problemy ze spełnieniem politycznych i ekonomicznych kryteriów członkostwa między innymi w zakresie funkcjonowania administracji państwowej i systemu sądownictwa, stabilności ekonomicznej, wysokiego poziomu korupcji, przestrzegania standardów demokratycznych ${ }^{74}$. Mimo tych negatywnych ocen, obawiając się konsekwencji, Rada UE ostatecznie zgodziła się na akceptację wniosku i przekazanie go Komisji ${ }^{75}$. Był to raczej gest symboliczny, co potwierdza opublikowany przez Komisje Europejską w listopadzie 2009 roku raport dotyczący integracji Czarnogóry z UE. Nie pozostawił on żadnych wątpliwości co do oceny postępów tego państwa we wdrażaniu unijnych reguł. Wskazano również wiele uchybień w odniesieniu do Bośni i Hercegowiny. Zwrócono uwagę na sytuację wewnętrzną państwa, problemy z utrzymaniem i zagwarantowaniem jego spoistości, stopień wprowadzania standardów państwa demokratycznego, walkę z korupcją i przestępczością zorganizowaną, sytuację gospodarczą i społeczną ${ }^{76}$. Sytuację Bośni i Hercegowiny dodatkowo komplikuje niestabilna sytuacja wewnętrzna i trudności w przebudowie ustroju państwa. Trwałym warunkiem kontynuacji procesu integracji Bośni i Hercegowiny z UE jest przeprowadzenie reformy konstytucyjnej, która wzmocni rząd centralny. Nalega na to usilnie UE, uzależniając kontynuowanie dyskusji o integracji od spełnienia tego wymogu ${ }^{77}$. Wzmocnienie władzy centralnej UE traktuje jako czynnik, który w przyszłości doprowadzi do wyeliminowania obecnej dziś nieufności między zamieszkującymi to państwo narodami, zachęci do współpracy i wdrażania reform.

W komunikacie z 14 października 2009 roku zatytułowanym Kosowo - realizacja perspektywy europejskiej Komisja Europejska zaproponowała rozpoczęcie procesu prowadzącego do zwolnienia obywateli Kosowa z obowiązku wizowego oraz prac przygotowawczych nad kompleksową umową w sprawie handlu, która miałaby zostać

lenderskiego weta. Zob. Serbia coraz blizej czlonkostwa w UE, „Rzeczpospolita”, http://www.rp.pl/artykul/25,554445-Serbia-coraz-blizej-czlonkostwa-w-UE.html.

73 Zob. D. Wybranowski, Bośnia i Hercegowina wobec Unii Europejskiej-trudna droga ku stowarzyszeniu. Problemy $i$ wyzwania polityki UE na Bałkanach Zachodnich na poczatku XXI wieku, „Wrocławskie Studia Politologiczne” 2009, nr 10, s. 221-225; D. Wybranowski, Nowe-stare państwo na mapie Europy. Czarnogóra między niepodległościa i Uniq Europejska, w: Unia Europejska w 2008 roku. Aktualne problemy i najważniejsze wyzwania, red. M. Musiał-Karg, T. Wallas, Poznań 2009, s. 137-156.

${ }_{74}$ Czarnogóra złożyła wniosek o członkostwo w UE, „Best OSW” 2008, nr 41.

75 Czarnogóra: Przełamanie impasu w polityce rozszerzenia?, „Best OSW” 2009, nr 16.

76 UE wobec Bałkanów - powrót polityki warunkowości, „Best OSW” 2009, nr 36.

77 Problem reformy konstytucyjnej w Bośni i Hercegowinie, „Best OSW” 2010, nr 34. 
podpisana, gdy Kosowo zacznie spełniać określone wymogi. Kontrowersje wokół niepodległego statusu Kosowa, nieuznawanie jego państwowości przez kilka unijnych państw powodują, że trudno jest wypracować spójną strategię działania wobec tej byłej serbskiej prowincji ${ }^{78}$. Unia Europejska musi wypracować w końcu wspólne, spójne stanowisko w sprawie Kosowa. Rozwój sytuacji politycznej i gospodarczej w Kosowie jest bowiem w znacznym stopniu uzależniony od UE i jej wsparcia politycznego, instytucjonalnego i finansowego, od niego zależy tempo wprowadzania wymaganych reform.

\section{Konkluzje}

Wzrost zaangażowania UE na Bałkanach wynika z przekonania o istnieniu zależności między bezpieczeństwem w regionie a bezpieczeństwem w Europie. Brak stabilności w Europie Południowo-Wschodniej może bezpośrednio zaważyć na bezpieczeństwie państw członkowskich. UE stała się więc jednym z podmiotów stabilizujących sytuację na Bałkanach. Oddziałuje ona na Bałkany Zachodnie na wielu płaszczyznach, stosując różnorodne instrumenty. Celem jest włączenie państw pojugosłowiańskich w orbitę europejskiej współpracy. Sukces tej polityki zależy od wielu czynników. Z pewnością sprzyja jej determinacja państw pojugosłowiańskich - ich konsekwentne proeuropejskie dążenia. Każde z tych państw jest jednak na innym etapie integracji. UE również jest zgodna co do kierunku kolejnego rozszerzenia, jednocześnie nie zamierza rezygnować z ustanowionych przez siebie warunków akcesji. Nie ma również mowy, kiedy mogłaby ona nastąpić. Unijni dyplomaci deklarują jedynie gotowość wsparcia państw bałkańskich w procesie integracji europejskiej.

Nieformalny szczyt UE-Bałkany w Sarajewie z czerwca 2010 roku $^{79} \mathrm{w}$ tej kwestii niczego nie zmienił. Nie podjęto żadnych konkretnych decyzji ani nie wyznaczono ram czasowych. UE nie chce się wiązać terminami. Na pewno ma na to wpływ sytuacja w Grecji - tonącej w kłopotach finansowych spowodowanych kryzysem światowym, a także korupcja w Bułgarii i Rumunii, co stanowi swoiste ostrzeżenie przed pochopnym i zbyt pośpiesznym przyjmowaniem kolejnych państw, zwłaszcza takich, które same borykają się z różnego rodzaju problemami. Dodatkowo sytuacja ekonomiczna UE nie jest najlepsza, konsekwencje kryzysu światowego poszczególne kraje unijne będą odczuwać przez najbliższe lata.

Warto jednocześnie podkreślić, że poszerzenie UE o kraje bałkańskie nie wiąże się z tak dużymi kosztami organizacyjnymi i finansowymi jak rozszerzenie z 2004 roku czy nawet 2007 roku. Łączna liczba ludności w państwach pojugosławiańskich wynosi około $21 \mathrm{mln}$, przyjęcie Bułgarii i Rumunii wiązało się z powiększeniem liczby ludności Unii Europejskiej o ponad $29 \mathrm{mln}$ obywateli ${ }^{80}$.

${ }^{78}$ Druga rocznica niepodległości Kosowa, „Best OSW” 2010, nr 8.

79 Nieformalny szczyt UE-Batkany Zachodnie bez znaczacych rezultatów, „Best OSW” 2010, nr 20.

${ }^{80}$ Dane dotyczące liczby mieszkańców krajów pojugosłowiańskich mają charakter szacunkowy. Opracowano na podstawie informacji zebranych i opublikowanych przez USA CIA ,The Word Factbook". Podobnie dane dotyczące liczby ludności Bułgarii i Rumunii pochodzą z tego źródła. Zob. https://www.cia.gov/library/publications/the-world-factbook/geos/ro.html. 
W obecnie obowiązującej unijnej strategii rozszerzenia postuluje się, by państwa zainteresowane rozszerzeniem wykazywały się nie tylko chęcią, ale i wysiłkiem. Przeprowadzanie reform politycznych i gospodarczych przy wsparciu ze strony UE może w przyszłości zaowocować członkostwem w unijnych strukturach. W wypadku państw pojugosłowiańskich (za wyjątkiem Chorwacji) jest to jednak daleka perspektywa. Oprócz uwarunkowań wewnętrznych, ważna jest unijna zgoda co do zasadności kolejnego rozszerzenia, gotowość struktur unijnych, zdolności finansowe. Istotne też są realne korzyści dla państw członkowskich. UE zdaje sobie sprawę, iż warunkiem stabilności na Bałkanach jest włączenie tego regionu w orbitę europejskiej współpracy. Pojawiają się jednak obawy, czy członkostwo państw pojugosłowiańskich będzie dostatecznym i wystarczającym hamulcem przed odradzaniem się narodowościowych konfliktów. Wprawdzie warunkiem rozszerzenia jest współpraca bilateralna w regionie, która ma służyć wytłumieniu sporów międzysąsiedzkich, w tym sporów na tle narodowościowym, jednak trudno zagwarantować trwałość dobrosąsiedzkiej współpracy $\mathrm{W}$ regionie.

Przed UE wcześniej czy później pojawi się konieczność udzielenia odpowiedzi, czy jest gotowa na rozszerzenie i kiedy. Państwa regionu bałkańskiego, a przynajmniej ich część, wcześniej czy później spełnią wymagania. Trudno sobie wyobrazić, by UE formułowała kolejne surowe kryteria.

Przed państwami pojugosłowiańskimi jeszcze dużo wyzwań, między innymi konieczność przekonania państw członkowskich do potrzeby kolejnego rozszerzenia. Rolę odgrywa nie tylko sprzeciw Grecji wobec członkostwa Macedonii czy Holandii wobec Serbii, lecz także obawy i innych państw. Przed Unią Europejską stoi z kolei konieczność zadecydowania, jak ma wyglądać unijna polityka zewnętrzna, czy ma się opierać na poszerzaniu europejskich struktur, czego konsekwencją staje się na obszarze bałkańskich między innymi dążenie państw pojugosławiańskich do przeprowadzenia reform na miarę Europy. W innym wypadku może dojść do wyhamowania demokratycznych przeobrażeń i kolejnych tarć w regionie. 